\title{
Prevalence of Agglutinating Antibodies to Toxoplasma gondii in Striped Skunks (Mephitis mephitis), Opossums (Didelphis virginiana), and Raccoons (Procyon lotor) From Connecticut
}

\author{
Author(s): Sheila M. Mitchell, Dennis J. Richardson , David S. Lindsay \\ Source: Journal of Parasitology, 92(3):664-665. 2006. \\ Published By: American Society of Parasitologists \\ DOI: http://dx.doi.org/10.1645/GE-800R.1 \\ URL: http://www.bioone.org/doi/full/10.1645/GE-800R.1
}

BioOne (www.bioone.org) is a nonprofit, online aggregation of core research in the biological, ecological, and environmental sciences. BioOne provides a sustainable online platform for over 170 journals and books published by nonprofit societies, associations, museums, institutions, and presses.

Your use of this PDF, the BioOne Web site, and all posted and associated content indicates your acceptance of BioOne's Terms of Use, available at www.bioone.org/page/terms of use.

Usage of BioOne content is strictly limited to personal, educational, and non-commercial use. Commercial inquiries or rights and permissions requests should be directed to the individual publisher as copyright holder. 


\title{
Prevalence of Agglutinating Antibodies to Toxoplasma gondii in Striped Skunks (Mephitis mephitis), Opossums (Didelphis virginiana), and Raccoons (Procyon lotor) From Connecticut
}

\author{
Sheila M. Mitchell, Dennis J. Richardson*, and David S. Lindsay†, Center for Molecular Medicine and Infectious Diseases, Department of \\ Biomedical Sciences and Pathobiology, Virginia-Maryland Regional College of Veterinary Medicine, Virginia Tech, 1410 Prices Fork Road, \\ Blacksburg, Virginia 24061-0342; *Quinnipiac University, Campus Box 71, 275 Mt. Carmel Avenue, Hamden, Connecticut 06518. †To whom \\ correspondence should be addressed. e-mail: lindsayd@vt.edu
}

ABSTRACT: The prevalence of agglutinating antibodies to Toxoplasma gondii was examined in striped skunks (Mephitis mephitis), opossums (Didelphis virginiana), and raccoons (Procyon lotor) from 8 cities in Connecticut. Ten $(42 \%)$ of the 24 striped skunks, 2 of 7 (29\%) opossums, and 12 of $12(100 \%)$ raccoons were positive at dilutions of 1:50 or greater. These results suggest that $T$. gondii is prevalent in the environment, or prey items, or both, of these omnivores in Connecticut.

Toxoplasmosis is a zoonosis, and all warm-blooded vertebrates are potentially susceptible to infection with this parasite. Oocysts excreted by domestic cats and other felines, as well as tissue cysts in prey, are sources of Toxoplasma gondii for domestic and wild animals. We are interested in the transmission of $T$. gondii in wild animals that are in contact with humans in urban areas (Hancock et al., 2005). The prevalence of antibodies to $T$. gondii in omnivores collected in urban areas should reflect the presence of oocysts in the environment and tissue cysts in food items of these animals.

Little is known about the prevalence of $T$. gondii in striped skunks (Mephitis mephitis) or opossums (Didelphis virginiana). Toxoplasma gondii genotype III was isolated from 3 of 6 asymptomatic striped skunks from Mississippi (Dubey, Parnell et al., 2004). Two of the 3 isolated from these skunks were mouse pathogens even though they

TABLE I. Prevalence of agglutinating antibodies to Toxoplasma gondii in striped skunks from 6 cities in Connecticut.

\begin{tabular}{|c|c|c|c|}
\hline City & Sex & Age & Antibody titer \\
\hline Branford & Male & Adult & $<1: 50$ \\
\hline Cheshire & Female & Juvenile & $1: 10$ \\
\hline Durham & Male & Adult & $<1: 50$ \\
\hline Madison & Female & Adult & $\geq 1: 500$ \\
\hline \multirow[t]{16}{*}{ Middletown } & Male & Adult & $\geq 1: 500$ \\
\hline & Female & Adult & $<1: 50$ \\
\hline & Male & Adult & $<1: 50$ \\
\hline & Male & Adult & $<1: 50$ \\
\hline & Female & Adult & $\geq 1: 500$ \\
\hline & Male & Adult & $<1: 50$ \\
\hline & Female & Adult & $1: 50$ \\
\hline & Male & Adult & $<1: 50$ \\
\hline & Female & Adult & 1:100 \\
\hline & Female & Adult & $1: 100$ \\
\hline & Male & Adult & $<1: 50$ \\
\hline & Female & Juvenile & $<1: 50$ \\
\hline & Male & Adult & $<1: 50$ \\
\hline & Male & Adult & $<1: 50$ \\
\hline & Female & Adult & $1: 100$ \\
\hline & Male & Adult & $<1: 50$ \\
\hline \multirow[t]{4}{*}{ Wallingford } & Female & Adult & $<1: 50$ \\
\hline & Male & Adult & $1: 100$ \\
\hline & Female & Adult & $<1: 50$ \\
\hline & Female & Adult & 1:100 \\
\hline
\end{tabular}

were molecularly consistent with the mouse avirulent genotype III. Toxoplasma gondii (genotype not determined) has been isolated from opossums (Smith and Frenkel, 1995). Many serosurveys indicate that T. gondii is highly prevalent in raccoons (Procyon lotor) from the United States (reviewed by Hancock et al., 2005). All 3 genotypes of encysted $T$. gondii have been isolated from the tissues of naturally infected raccoons (Lindsay et al., 1997; Dubey, Graham et al., 2004). The present study was conducted to determine the prevalence of agglutinating antibodies to $T$. gondii in striped skunks, opossums, and raccoons from Connecticut.

Sera from 24 striped skunks, 7 opossums, and 12 raccoons from urban or peri-urban areas in 8 cities in Connecticut were examined for agglutinating antibodies using the modified direct agglutination test (MAT) for T. gondii employing formalin-fixed, RH strain tachyzoites as antigen (Dubey and Desmonts, 1987). Animals used in this study were collected alive with the assistance of nuisance wildlife control personal in Connecticut. They were collected in the cities of Branford, Cheshire, Hamden, Madison, and Wallingford in eastern New Haven County and Durham, Killingworth, and Middletown in western Middlesex County. Animals were humanely killed. Blood was obtained immediately at death by cardiac puncture and placed into a collection tube. The serum was collected and placed in a microcentrifuge tube and frozen at -70 C. Frozen sera were sent to the Center for Molecular Medicine and Infectious Diseases, Department of Biomedical Sciences and Pathobiology, Virginia-Maryland Regional College of Veterinary Medicine, Virginia Tech, Blacksburg, Virginia, for MAT. Sera were examined at dilutions of 1:50, 1:100, and 1:500 in the MAT.

Sera from 24 striped skunks collected in 6 cities were examined. Thirteen were male, and 11 were female. All males were adults, 9 females were adults, and 2 were juveniles. Their collection locations are presented in Table I. Sera from 7 opossum (4 males and 3 females; all adults) and 12 raccoons ( 8 males and 4 females; all adults) were also examined (Table II).

Ten $(42 \%)$ of the 24 sera collected from striped skunks were positive (Table I). Sera from 5 males were positive, and sera from 6 females were positive. One of the 2 juvenile females was MAT-positive at a dilution of 1:100 (Table I).

TABLE II. Prevalence of agglutinating antibodies to Toxoplasma gondii in raccoons and opossums in 8 cities from Connecticut.

\begin{tabular}{lll}
\hline \multicolumn{1}{c}{ City } & \multicolumn{1}{c}{ Number of raccoons* } & \multicolumn{1}{c}{$\begin{array}{c}\text { Number of } \\
\text { opossums } \dagger\end{array}$} \\
\hline Branford & 0 & $1(<1: 50)$ \\
Cheshire & $4(1: 100 ; 1: 50 ; \geq 1: 500 ; \geq 1: 500)$ & $2(<1: 50 ;<1: 50)$ \\
Durham & $3(1: 100 ; 1: 100 ; \geq 1: 500)$ & 0 \\
Hamden & $1(\geq 1: 500)$ & 0 \\
Killingworth & 0 & $1(<1: 50)$ \\
Madison & $2(1: 50 ; \geq 1: 500)$ & $1(1: 100)$ \\
Middletown & $1(\geq 1: 500)$ & $1(\geq 1: 500)$ \\
Wallingford & $1(\geq 1: 500)$ & $1(<1: 50)$ \\
\hline
\end{tabular}

* All raccoons were positive (titer) for $T$. gondii in the agglutination test.

$\dagger$ Two of 7 opossums were positive (titer) for $T$. gondii in the agglutination test. 
Sera from $2(29 \%)$ of the 7 opossums were positive in the MAT, and all of the sera samples from the 12 raccoons were positive in the MAT. Locations of the 8 cities from which animals were collected and MAT titers are given in Table II.

Franti et al. (1976) found that 7 (22\%) of 32 striped skunks from northern California were positive for antibodies to $T$. gondii in the indirect hemagglutination test. Schowalter et al. (1980) reported that 81 $(15 \%)$ of 542 of striped skunks, collected in the prairie of Alberta and Saskatchewan were positive for antibodies to $T$. gondii in the indirect hemagglutination test. Smith et al. (1992) found that $2(29 \%)$ of 7 striped skunks from swine farms in central Iowa were positive in the MAT, and Hill et al. (1998) found that 38 (47\%) of 81 striped skunks from Iowa were positive in the MAT. These findings are similar to the $42 \%$ prevalence reported in the present study.

Smith et al. (1992) reported that 1 (3\%) of 34 opossums from swine farms in central Iowa were positive in the MAT, and Hill et al. (1998) reported that $12(23 \%)$ of 53 opossums from Iowa were positive in the MAT. The finding of $29 \%$ prevalence in opossums in the present study is only slightly higher than that of Hill et al. (1998).

All the raccoons in the present study presented serological evidence of $T$. gondii infection. Hancock et al. (2005) reviewed the serological prevalence data on raccoons in the United States and reported that studies indicated that from 15 to $84 \%$ of raccoons examined using the MAT were positive.

We thank Peter Aubrey for assistance in collection of animals. Supported in part by a BRIDGE grant, Virginia-Maryland Regional College of Veterinary Medicine to D. S. L. and a grant from the Faculty Research Committee, Quinnipiac University to D. J. R.

\section{LITERATURE CITED}

Dubey, J. P., And G. Desmonts. 1987. Serological responses of equids fed Toxoplasma gondii oocysts. Equine Veterinary Journal 19: 337-339.

, P. G. Parnell, C. Sreekumar, M. C. Vianna, R. W. De Young, E. DAHL, AND T. LeHMANN. 2004. Biologic and molecular characteristics of Toxoplasma gondii isolates from striped skunk (Mephitis mephitis), Canada goose (Branta canadensis), black-winged lory
(Eos cyanogenia), and cats (Felis catus). Journal of Parasitology 90: $1171-1174$

, D. H. Graham, R. W. De Young, E. Dahl, M. L. Eberhard, E. K. Nace, K. Won, H. Bishop, G. Punkosdy, C. Sreekumar, M. C. Vianna, S. K. Shen, O. C. Kwok, J. A. Sumners, S. Demarais, J. G. Humphreys, And T. Lehmann. 2004. Molecular and biologic characteristics of Toxoplasma gondii isolates from wildlife in the United States. Journal of Parasitology 90: 67-71.

Franti, C. E., H. P. Riemann, D. E. Behymer, D. Suther, J. A. HoWARTH, AND R. RUPPANNER. 1976. Prevalence of Toxoplasma gondii antibodies in wild and domestic animals in northern California. Journal of the American Veterinary Medical Association 169: 901906.

Hancock, K., L. A. Thiele, A. M. Zajac, F. Elvinger, And D. S. LindSAY. 2005. Prevalence of antibodies to Toxoplasma gondii in raccoons (Procyon lotor) from an urban area of Northern Virginia. Journal of Parasitology 91: 694-695.

Hill, R. E., JR., J. J. Zimmerman, R. W. Wills, S. Patton, and W. R. ClARK. 1998. Seroprevalence of antibodies against Toxoplasma gondii in free-ranging mammals in Iowa. Journal of Wildlife Diseases 34: 811-815.

Lindsay, D. S., C. A. Sundermann, J. P. Dubey, and B. L. Blagburn. 1997. Update on Toxoplasma gondii infections in wildlife and exotic animals from Alabama. Journal of the Alabama Academy of Science 68: 246-254.

Schowalter, D. B., J. O. Iversen, L. C. Corner, and J. R. Gunson. 1980. Prevalence of antibodies to Toxoplasma gondii in striped skunks from Saskatchewan and Alberta. Journal of Wildlife Diseases 16: 189-194.

Smith, D. D., AND J. K. Frenkel. 1995. Prevalence of antibodies to Toxoplasma gondii in wild mammals of Missouri and east central Kansas: Biologic and ecologic considerations of transmission. Journal of Wildlife Diseases 31: 15-21.

Smith, K. E., J. J. Zimmerman, S. Patton, G. W. Beran, and H. T. HiLl. 1992. The epidemiology of toxoplasmosis on Iowa swine farms with an emphasis on the roles of free-living mammals. Veterinary Parasitology 42: 199-211.

\title{
A Simple Molecular Technique for Identifying Marine Host Fish by Sequencing Blood-Feeding Parasites
}

\author{
L. Nagel and S. C. Lougheed, Department of Biology, Queen's University, Kingston, Ontario, Canada K7L 3N6. e-mail: \\ nagell@biology.queensu.ca
}

ABSTRACT: Gnathiid isopods are common ectoparasites of fish on the Great Barrier Reef, Australia. While screening for appropriate markers for phylogenetic studies of gnathiids, we found that primers for $12 \mathrm{~S}$ and 16S rDNA preferentially amplified the host fish DNA instead of gnathiid DNA. This amplification occurred even when using gnathiids that were not engorged with host blood and adult gnathiids that do not feed on fish blood. This method could be used in host-parasite studies to identify hosts without having to sample parasites directly from the host (which can be costly and requires considerable skill in a marine environment). Target ribosomal DNA sequences can be amplified from total DNA extracted from parasites that are captured in funnel traps or plankton tows. Sequence data from these can be used to identify the hosts that gnathiids were feeding on before capture.

Gnathiid isopods (Gnathia spp.) have been found on $70 \%$ of 56 species of reef fish surveyed on the Great Barrier Reef (Grutter and Poulin, 1998). Gnathiids can inflame and destroy mucosal tissue, causing bacterial infections (Honma and Chiba, 1991), and they are known to kill captive fish if they are present in high densities (Paperna and Por, 1977;
Mugridge and Stalleybrass, 1983). They also lower hematocrit levels of their hosts (Jones and Grutter, 2005). Gnathiid infestation on the Great Barrier Reef seems to be very high. Grutter (1996) showed that after the number of gnathiids on the labrid host fish Hemigymnus melapterus was experimentally reduced, gnathiid loads doubled $24 \mathrm{hr}$ after the manipulation.

Gnathiids are crustaceans in which only the juvenile stages (1-3 mm) feed on fish blood and plasma (Monod, 1926; Grutter, 2003). After proceeding through 3 juvenile stages (feeding and returning to the benthos to molt at each stage), they molt to adulthood (after approximately $1 \mathrm{mo}$ ). They live in the benthos in this stage, mate, and do not feed (Monod, 1926). Little is known about host preferences or methods of host detection in gnathiids (or most other marine ectoparasites). Studies ranging from basic ecology to host parasite coevolution require information on the hosts that parasites feed on in their natural environment. A method for identifying host fish without requiring the sampling of the parasite directly from the host would be invaluable because host capture can be time-consuming and requires considerable skill. Here, we describe a method that allows for the identification of host fish to 